\title{
The Influence of Folklore on the Cultivated Albanian Music of the XX Century
}

\author{
Denis Bizhga \\ PhD Cand., Lecturer, European University of Tirana
}

\begin{abstract}
Folklore is one of the components and transmitters of a nation's national identity and its spiritual heritage. The great folkloric wealth of Albanian people shows its antiquity and creative genius. As the first creation of folklore, it is the basis for the creation and continuous functioning of other cultivated arts, such as: music, literature, choreography or other visual arts. Albanian folklore also represents a vital, early, stable and rich tradition. It is not a memory of the past, but it is alive and full of life and day by day it comes and is practiced articulated emotionally, developing, enriching and growing together with the Albanian people themselves, despite the many changes that are noticed in the realities of Albanian folklore in general. Through folklore, our people over the centuries manifested outstanding talent, spiritual expressive potential, great promotional skills. Albanian folk music tradition is generally an oral tradition based on the memory of the people; she did not feel the need for writing because she was born, spread and selected to live word of mouth and generation after generation, adapting to the needs and requirements of life.
\end{abstract}

Keywords: Folklore, Albanian Music, Nation Identity, Cultivated Music

\section{Introduction}

Folklore is one of the components and transmitters of a nation's national identity and its spiritual heritage. The great folkloric wealth of our people shows its antiquity and creative genius (Paparisto,1970). As the first creation of folklore, it is the basis for the creation and continuous functioning of other cultivated arts, such as: music, literature, choreography or other visual arts. Albanian folklore also represents a vital, early, stable and rich tradition. It is not a memory of the past, but it is alive and full of life and day by day it comes and is practiced articulated emotionally, developing, enriching and growing together with the Albanian people themselves, despite the many changes that are noticed in the realities, of Albanian folklore in general (Kapxhiu,2015). Through folklore, our people over the centuries manifested outstanding talent, spiritual expressive potential, great promotional skills (Kuqi,2018). Albanian folk music tradition is generally an oral tradition based on the memory of the people; she did not feel the need for writing because she was born, spread and selected to live word of mouth and generation after generation, adapting to the needs and requirements of life. When the Albanian language began the path of transformation from the form of rural dialects to the more urban ones, this fact did not occur as a result of the beginning of the use of the Albanian script, but of the adoption of people's speech in newer living conditions. From this adaptation, the musical tradition of the cities gained a new dimension. The Albanian language, although transmitted and preserved in the memory of the people, needed writing, which it lacked for a 
long time, while the oral, urban and rural musical tradition did not feel such a lack (Koço,2004). As the Albanian language began to be written relatively late, the people's memory of his epic and song continued to be particularly strong and prevalent until the twentieth century, while the Albanian musical tradition was subject to three main laws of oral transmission: continuity, change and selection. Regarding the musical writing according to the Western system, it must be said that we are lucky because it started to be used not much later than the somewhat unified writing of the Albanian language (Koço,2004). Around the '30s, the rich civic song of the different regions of Albania, in addition to the form of interpretation given by its natural traditional oral bearers, began to be presented to the public in the form of cultivated music (savante). The relationship of folklore with cultivated musical creativity finds expression in almost all forms, genres and genres of professionally cultivated artistic music (Kapxhiu,2018). Since the century. XIX, in European countries was promoted the recognition, study and possible use of national musical heritage in order to form musical cultures with a national spirit, a direction which influenced the developments of Albanian music at the beginning of the century. XX. Among the relations between folk and cultivated music are mentioned harmonization, elaboration, creation in folk style and quotation from folk music (Kapxhiu,2018).

Folk music, characterized by simplicity of expression, rich emotional, melorhythmic, modaltonal, linguistic and structural content has been used by Albanian composers to perfect cultivated musical creativity. Singers, professional pianists and composers of the 1930s, began to build and harmonize civic folk songs by including them in their programs in which the classical repertoire dominated. Civic lyrical songs that had begun to be cultivated by artists of the 30's and that were later reflected in the collection: "Albanian Lyra", drew the attention of critics, local and foreign, on the values and role of these songs. The civilized world noticed in these songs a lack of, the passion of forbidden love, the provincial diversity in the expression of beauty (text and music), the metric and modal diversity as well as the identity of the main provinces of Northern, Central and Central Albania. South; she felt in these songs "the melancholy of despair, the suffering with hope, the desire for the renewal of genesis (Koço,2004). Civic songs carried down by generations of their deliverers from the "twilight" of anonymity to the present day have always tended to change perhaps never to reach any final form if their collector had not ever appeared to them. fixing them on paper at a certain stage of development (Koço,2004).

One of the three most important factors of folk music is continuity, which is essential for the musical tradition which mainly matures through the process of oral transmission. Thus, if continuity were what connects the present with the past and selection determines the most accomplished music, change would be what stimulates the creative impulse of the individual or group. Since the traditional civic song lives only through the oral form (that is, it does not need the musical writing of reference) and is always in search, change as an integral element of this oral musical tradition becomes an important factor in creating new forms. of songs (Koço,2004). Although changing the same song over time has been a stimulus to creation, the song itself during the continuum process has not always been inclined towards improved maturity; it may even have been lost in memory. Not a few songs during the oral broadcast have suffered such a fate. As for the civic songs (anonymous or with an author) that have not only preserved the memory but have been evidenced for their values, have their origin in the original, if the latter can be researched and it should be considered as the source and accurate model of the song (Koço,2004). 
The delivery of folklore and language, as important components of the spiritual and material cultural heritage, according to the appropriate artistic and professional criteria, gave the cultivated music a unique originality. Moreover, Albanian folk music has influenced the crystallization of forms of melodic development of professionally cultivated music through the preservation, use and reliance on folk intonations. During the process of transmission and oral development of Albanian civic songs, the Western system of major minor minor tones was completely irrelevant to these songs. The musical influence of the West in Albania that can be said that from the second half of the XIX century was characterized by the following factors: the structure of songs (strophic or chorus); use of Western instruments with tempered intonation; adaptation from a rhythmically free syllabic ornamentation (typical of that of the Middle and Near East) to a more balanced and rhythmic ornamentation in the distribution of grades; accompaniment of songs from the orchestra instead of the earliest local formations (saz party). The use of the Albanian language in songs, despite the number of words and accents in Turkish, was what nationalized it more than anything else. Despite these new influences, the civic song mainly of northern and central Albania carried essentially characteristics of the East, Oriental-Balkan but with a distinct provincial identity; for the sake of these features it has a value of unrepeatable local originality. Regarding the civic song of the south, mainly that of the district of Korça, it deviates from the fashions of the South-Western Balkans. Both the fashions of the Western Balkans and the Ottoman fashions originate from the Orient but belong to different periods. In the formation of the character of the Albanian civic song, the Ottoman modes have had a greater influence, which are characteristic for the songs of Central and Northern Albania, which are closer to the diatonic modes. Some types of songs, have been influenced not only by geographical position but also as a result of Byzantine and Ottoman rule for a long time (Xhatufa,2003). Folklore has consistently been a source of inspiration and orientation for the delivery of our cultivated music. The first professionals of our musical tradition in the creative field, such as: Lec Kurti, Father Martin Gjoka, Thoma Nasi, Krito Kono, Pjetër Dungu, Konstandin Trako, etc., who in their creative beginnings showed serious efforts to orient their musical work from the provincial folk music of their origin (Kapxhiu,2015). The research and musicological works of various scholars, in modern times, through internationally accepted documents and justifications, have brought to light important data on the contribution and precious values in cultivated music (Kuqi,2018). Folk music motivated and led the formative process of cultivated music as the only national artistic tradition with uninterrupted continuity. Thus, the relationship between folk and cultivated music developed in several key steps.

The first step in establishing the relationship between folklore and cultivated music is the harmonization of folk songs, especially those for the vocal formation of disazers (Kapxhiu,2016). Harmonization is about the harmonious modal, diatonic and chromatic attire of popular music.

European national schools, such as Russian, Czech, Hungarian, Polish, Norwegian, etc. during the century. XIX have played an important role in uniting the national concept (struggle for identity and national unity) and the popular one in cultivated music. We find this process developed in the Baroque period of classical classicism and romanticism in the century. XIX. Also, the harmonization of folk songs takes place on the stage forms of the vocal-orchestral genre, such as opera and operetta.

Harmonization, as a form of the early relationship of folklore with cultivated music, has been widely practiced by Albanian composers after the 30 s and 40 s of the last century, ie later than 
in other peoples, aiming at shaping the character and national spirit. As in Europe, in Albania, folk music was the motive and leadership of the creativity of cultivated music, as an important part of the artistic and spiritual heritage of the Albanian national culture. Based on the limited degree of qualification of the Albanian composers of this period, their creativity of harmony was focused on vocal formations with popular spirit, which were simple in terms of dimension and articulation. Moreover they were closer to the musical tastes of the public of that period. Among the Albanian composers who harmonized folk songs for different vocal formations are mentioned Çesk Zadeja, Tish Daija, Tonin Harapi, Mark Kaçinari etc.

However, the earliest evidence for the delivery of cultivated music dates back to the National Renaissance period. The National Renaissance valued folk music, and especially song, as an important and indispensable tool for reflecting and disseminating its progressive ideas (Kuqi,2018). During this period, folk music came out of the closed provincial circle and, step by step, began to be compared to its national sisters and to the new cultivated Albanian music.

A more advanced stage of folk music elaboration is the in-depth development in cultivated music, which involves the transformation of the thematic source material in accordance with the sound wholeness of the folk source music (Kapxhiu,2016). Through compositional tools and techniques such as: the development of thematic material, ameliorative changes of the source music subject, tonal shifts, harmonization, etc., folk music comes even closer to cultivated artistic musical creativity. The elaboration of folk music began as a need to adapt folk creations to wind orchestras and between the 30s and 40s of the century. passed also for adapting to different coral formations.

After the Second World War, it was necessary for art to serve the improvement of the Albanian social life, that is, the education of the masses and the strengthening of the national character. Attention was paid to increasing the number of professional composers who would deliver musical creativity in close connection with folk music of a national character.

This fact is also expressed by A. Paparisto, when he states that: "The first step in creating a national music was the elaboration or use of the song, the folk melody. The values of such work are seen in the fact that the composers, who less and who more, have made this elaboration starting not only from the purpose of technical enrichment, but also defining a point of view and creating from the old material folkloric new emotions " (Paparisto,1970).

The elaboration of folk music for vocal formations was masterfully realized by Kostandin Trako, Lorenc Antoni, Fahri Beqiri, Tonin Harapi, etc., a tradition which was transmitted to composers after the '70s and' 80s such as Limoz Dizdari, Gjon Simoni, Thoma Simaku, Vasil Tole et al. Their creative individuality served to deepen the national character of Albanian artistic music, especially the vocal one cultivated through the form of folk music processing.

For T. Harapin "Elaboration is a new work, despite the fact that the original source was taken from the people: therefore it must be distinguished by an architectural construction, a clear form which conveys the thought from one stage to another, gives way and creates the necessary correlation to emotion and inner nerve. Here, the artistic mastery, sharpness and taste of the composer play a special role " (Kalemi,2003).

Albanian composers of the second half of the last century have relied on folk music to deliver processing and harmonizing forms of vocal and instrumental music. Moreover, according to T. Harapi, "The task of any elaboration is to preserve and strengthen the genuine source emotion. If the source material takes a different direction or is lost during processing, then we have 
escaped the basic demand of this genre." Albanian composers, by establishing stable relations with the processing and harmonization of folk music, paved the way for the delivery of vocal and orchestral forms, with a national spirit. According to T. Harapi "By elaboration we mean the expansion, multiplication of ideological, emotional, stylistic and technical values of the popular source material. The elaboration starts from the increase of the volume (sound) of a folk song, until the realization of an architectural choral, orchestral or solo construction; since the harmonization with many voices, with many instrument lines, etc. Without going into the details of the processing scale, we can say that it is another edition of the folk song, more reinforced in many ways. The elaboration of folk music is closely related to the creative individuality of the composer, ie the fact how much he knows folk music, how emotionally connected it is with the spiritual heritage of the people and how professional he is in performing this practice. First, he selects a popular subject as original and practical as possible. Second, it studies and analyzes popular music. Third, it finalizes and enables the performance of a complete artistic and emotional creation. Also, the processing of folk music has led to the delivery of musical forms and genres with a wider vocal and instrumental dimension.

In addition to the process of processing and harmonizing folk music for choral formations, another form is the way of creating popular style music as an independent development of cultivated music. This form is evident in the song genre for soloists or vocal formations. The characteristic of these creations is that although they do not rely on any authentic folk creation to quote and further develop it, most of them come oriented towards general characteristics of folk songs and, more often, inspired by folk music. provincial origin of the author (Kapxhiu,2016). In this way, the original styles of folk songs are different in terms of syntactic features, melo-dramatic structure, etc.

The creations of Albanian composers with provincial folk style and artistic-emotional achievements are numerous, both for the solo genre and for the vocal formations. Famous are the civic songs of Shkodra, Elbasan, Berat, Korça, etc., such as "Luleborë", authored by S. Gjoni, "When my husband comes from the camp", by K. Konon, etc., some of which are also known as folk songs without author. In the period of the Anti-Fascist National Liberation War, folk songs played an important role in awakening and deepening the patriotic spirit. In the period during the second half of the last century, popular style musical creations developed further. The songs stand out: "Kur bjen fyelli dhe çiftelia" by P. Gaci; "Gajdexhiu", by T. Daija; "Xhamadani vija-vija", by Mr. Çoba etc. In continuation, Albanian composers showed their creative individuality in songs, dances, various instrumental and orchestral pieces in folk style, which enriched the artistic life of the country.

The creation of popular style of cultivated music was a new and independent development that further expanded the popular spirit and national character, as well as the delivery of genres and major forms of symphonic, stage, vocal, instrumental and chamber art music. Mainly, this style was developed in the genre of civic song and music adapted for folk instruments, such as: llahuta, çiftelia, fyejt etc. Another form of relationship between folk and cultured music is the citation of authentic musical material of songs, instrumental and orchestral pieces of folk music and its inclusion in the cultured musical work in the vocal, homophonic, polyphonic, instrumental, orchestral genres, especially the music of the ensemble of Central Albania and that of the sazes of Southeast and Southern Albania, chamber music, vocal-concert music and stage music for opera and ballet. Citation of folk music, as an important aspect of cultivated artistic music has emerged in the years 1930-1990 onwards. In this way, the folk music tradition has oriented the formation and crystallization of the 
professionally cultivated musical tradition. The citation form from folk music dates back to the period of Romanticism of the century. XIX, where various Russian, German, Norwegian, Italian and wider composers combined their creativity with folk music resulting in orchestralsymphonic works, such as rhapsody, dance, etc. Some of these quotations are those of the opera "Tanhoizer", of R. Wagner, the opera "Evgeny Onjegin", of P. I. Tchaikovsky, etc. In the century. XIX, the Hungarian composer, F. List says about the Hungarian rhapsodies "I took the wealth of motives where they had their source" (Lara,1984). Even throughout the century. XX, many composers like M. Ravel, B. Bartok etc. they based their creativity on folk music by giving it a national character and also clarifying their creative individuality. According to the Hungarian composer and ethnomusicologist B. Bartok "To create based on folk songs, this is one of the most difficult tasks or otherwise not easier than to create works with original themes. Suffice it to keep in mind that the elaboration of a certain theme is in itself the source of a great difficulty in the elaboration of the folk song or in its simple harmonization, such inspiration is also required, as in the creation of a written work with a theme. created by the composer " (Bartok,1954). Based on the achievements of the musical creativity of composers of the century. XIX, XX was also oriented the Albanian musical direction and the original abundant creative practice of Albanian composers. One can single out "Rhapsody on Albanian folk songs" by M. Gjoka (1922) with quotes from the folk music of northern Albania, etc. After the 50s of the century. XX examples of citation through folklore are the works of Albanian composers, such as: Zadeja, Daija, Zoraqi, Harapi, Dizdari, etc. After the Second World War, musical creativity reflected the social, political and cultural transformations in Albania, in other words, she became the spokesperson of this era. The citation of the popular source material was reflected in the genre of vocal and orchestral rhapsody around the 40s of the last century. The composer K. Kono stands out, who composed five rhapsodies. Folk music with its morphological, syntactic and expressive richness enabled a cultivated and original musical creativity. In the period after the 60's of the last century, rhapsody as a genre of orchestralsymphonic music started and was widely cultivated. The rhapsodies of Laro, Gaqi, Peçi, etc. stand out, in which a series of well-known folk songs and dances of the traditional folk music were quoted. One problem in this regard has been the decline in folklore of various composers, otherwise the formal copying of a folk melody or a segment of instrumental folk music, without undergoing processing, through compositional tricks, impoverishes the creative process of creativity cultivated in the orchestra genre. , poem and symphonic dance etc. as well as the creative individuality of the composer. The reason is the professional lack of knowledge of musical means of expression and compositional techniques.

However, folk music found the right expression in the creativity of most Albanian composers in order to realize the national in music. We mention the long research and cognitive work of C.. Zadesa in the relationship of his creativity with folklore.

Kosovar composer and musicologist A. Koçi underlined: "Professor Zadeja is a composer who represents the greatest creative figure in our national universe and at the same time belongs to the first generation of our educated composers, who laid the foundations of classical music with wide dimensions, such as from the aspect of the treatment of the musical subject and the artistic form, as well as from the aspect of the melody, rhythm and style (Koçi,2008). Delivering the genre of rhapsody of this period relied on the great epic through its citation, elaboration and recreating in popular spirit and national character, which further inspired the creativity of the '70s-' 90 s of the last century. For example, the folklore of the villages of Tirana adapted best to the cultivated music. On the one hand, a folklore motif of a musical work, of 
whatever genre it may be, makes it possible that that motif, even if it is sung by the people, is not lost as a heritage, because it is found in that work, while on the other hand, if we were to cultivate a folk song, it can no longer be called folk, because it must be free to undergo changes or be preserved as it is, depending on the bearers (Kuqi 2018). Despite this reasoning, folk music remains a model and aspiration for the cultivated Albanian music, which has been developed oriented towards it and the rich long tradition. The folk song has been adapted by the composers in different ways, during the process of multiplication and enrichment of the cultivated Albanian music in different genres and forms. Composer Aleksandër Peçi at the 28th song festival on RTSH, in 1989, with the song "Toka e Diellit", sung by Frederik Ndoci, Manjola Nallbani, Julia Ndoci, won the first prize. Her motive was taken from a folk song, which belongs to the villages of Tirana, "The river is coming, the river is lying" or, as it is also known, "This Lik Stema is making a gun". This composer, like many others, has made the best use of folklore, in particular, that of the villages of Tirana. Other works of this composer based on the folklore motifs of the villages of Tirana, are: "Dance Triste", with a motif taken from "The flower cries for the flower"; "Dance on glass", with motif taken from "Dance No. 1 of Tirana"; "Dance Rhapsody", with motif taken from "Napoleon", "Four dances for violin and piano", taken from "Black Day" , mre, dit 'e hon', mre ". Moreover, this composer has other works, based on the folklore motifs of the villages of Tirana, such as: the wolf motif in the ballet "Kids and the Wolf" and the film of Skanderbeg, the wedding moment. Another composer who referred to the motifs of Tirana folklore is Pëllumb Vorpsi, who built his work, entitled "Fantasy" for orchestra and choir (wordless choir, with vocals), processing the motifs of the dance of " Napoleon ". Moreover, he has also developed folk songs for the acapella choir. Even the music of the documentary film "Frang Bardhi" has a popular character and is perceived as such, although there are no motives taken specifically for any particular song. Pëllumb Vorpsi says: "Popular material never hinders the modern one". Also, the composer Thoma Gaqi is based on the motives of folk songs of the villages of Tirana. With the motive of the song "Po lje lumi rrema rrema" ("Po ban pushk 'o ky Lik Stema"), he has built the second theme of "Dublit Rapsodi, Concerto for violin, cello and orchestra", created in 1979, while in in 1977 "Rhapsody No. 1 for orchestra", the middle part of it, was built with the motif of the song "Çohuni djem shaloni atin", while the third part, which is allegro, was built with the motif of the song "Lake pupulake". All the time is built on motifs with magnified seconds and the motifs are scattered all over, in different positions, are opened in different positions.

Another work of this composer is the symphonic dance "Dance with tears", of 1981, which is built on the motif of "Dance No. 3, of Tirana" (dance of the bridegrooms). Composer Thoma Gaqi, realizing best that the difficulties for composers who take folklore motifs for their works are of different natures, says: "I have been attracted by the autochthony of these songs, they are very old folk songs, it is not easy to mutilate. Being quite old they have taken place in the people and great care must be taken because it is much easier to fail than to succeed so as not to become disliked by the people. You need to think about why you should and why you are taking advantage of this. Folklore is used all over the world. " Another example of the influence of folklore can be seen in the Albanian choral song, which came and developed as an example of folk group singing, which although characteristic of southern Albania, is practiced in other territories of the country, such as Myzeqe , Chameria, in Kosovo, in Albanian lands, in eastern Macedonia, etc. The way in which the relationship between choral singing and folklore develops is expressed in various forms, such as the elaboration, harmonization and creation of folk songs for choir. Moreover, stylization means a vocal-choral creation that contains quotations from folk songs, developing them melodically, in a popular spirit, and structuring 
them in polyphonic harmony. C.. Zadeja would say: "Musical creativity, folklore, has been used in the most natural ways, starting from the method of quotation, elaborated according to the creative individuality of the composer. In many cases, the innovative modal-harmonic source of popular creativity, has maintained its importance, as well as other elements such as the richness of melodic figurations, rhythmic variety, instrumental colors, etc .. when we talk about these achievements, we must understand the way more conscious that in these cases we have nothing to do with primitive ethnographic interventions, as if we do not have to go so far with our intervention, where we lose all signs of folklore ". Folklore has long been the only creative artistic consciousness of our people in terms of music. The national identity of our cultivated music cannot be understood without its relationship to folklore (Turku,2018). He is its main source. Moreover, the deep knowledge and study of folklore creativity is a necessary condition for musical realizations with clarity of national identity. On this problem, Albert Paparisto underlines: "These important problems for the enrichment of our new national tradition can not even be thought to be solved without folklore, without a new direction of creative practice towards folklore. And this new direction is not only its exploitation from the melodic and rhythmic point of view, but the study and discovery of the deeper features, the development of those embryonic characteristics that hide these melodies, the discovery and development of the expressive logic of their inner nature (Paparisto,1970).

The works with folklore motifs are very successful and liked by the Albanian public because they are very close to it. Moreover, folklore has helped artists create and develop an identity of their own with a national character. Prof. Alfred Uçi states that "It would not be appropriate to deny the popular spirit to many works of professional art, which do not carry direct influences from folklore .... Strengthening the ties of professional art with folklore not only has not been and it is not an obstacle for raising the level of artistic mastery, but it is a premise for strengthening the popular spirit of the professional socialist art ..." . The latter reasoning is based on the fact that in the period of the communist regime there were controversies over the connection of folklore with professional art. Research has proven that in different historical periods, Albanian authors have highlighted the desire and efforts to preserve national identity in cultivated music, through the development of relations with folklore. Cultivated Albanian music has always been multiplying and enriching both in genres and in forms and languages, and in support of this music has been folklore. Currently, the cultivated Albanian music is preparing important conceptual changes, which come naturally, as a necessity of the path towards European integration, where popular orientation is a priority and a factor, not only for the configuration of its national identity, but also for the authenticity of originality, which he will place with dignity, alongside the musical cultures of the peoples of a united Europe. Every creator, without exception, even contemporary ones, is based on the sensory authenticity of folk music.

\section{References}

[1] Paparisto (1970)"Tradita Kombëtare dhe roli i saj në krijmtarinë tonë", Gazeta "Drita"

[2] Koci (2008) "Vibracione të shpirtit shqiptar", vëll. I, Bukuresht

[3] Kapxhiu (2016) "Folklori dhe kompozitorët shqiptarë". Shkolla doktorale

[4] "Etnologji-Folklor", Qendra e Studimeve Albanologjike, Tiranë,

[5] Bartok (1954) "Tri leksione mbi muzikën hungareze", revista "Uj zenei szenie"

[6] Eno Koço (2004) "Shostakoviç dhe Kadare \& artikuj, profile, intervista e vrojtime mbi artin muzikor shqiptar" Shtëpia Botuese Uegen. Tiranë

[7] Kreshnik Kuqi (2018) "Krijmtaria folkloriste e fshatrave të Tiranës dhe muzika e kultivuar". Gazeta shqiptare 
[8] K. Lara, T. Harapi dhe A.Paparisto,(1985) "Analiza e veprave muzikore", SHBLU, Tiranë,

[9] "Këndon lahuta e çiftelia", Vargje origjinale nga rapsodë këngëtarë e bejtaxhi popullorë të rrethit Lezhë. Botim i Shtëpisë Kulturore Lezhë, 1961.

[10] Osman Xhatufa (2003) "Kultura Popullore". "Kënga Lirike Qytetare Shqiptare Në Vitet 1930". Botim i Akademisë së Shkencave. Tiranë 2003

[11] S. LI. Kalemi, "Tonin Harapi", (2003) (Monografi), Shtëpia botuese. "Gjergj Fishta", Tiranë

[12] Suzana Turku (2013) "Folklori muzikor dhe muzika skenike shqiptare" (Këndimi koral shqiptar dhe rrënjët e tij popullore dhe kombëtare). Tezë në kërkim të grades shkencore "Doktor", Shkolla doktorale e studimeve etnomuzikologjike, Tiranë 